\title{
Optimizing Edible Film from Corn Cobs with Surface Response Method
}

\author{
Ni Ketut Sari ${ }^{1 *}$, Adelia Hayu Regita ${ }^{1}$, Dimas Wahyu Dwi Putra ${ }^{1}$, Dira Ernawati ${ }^{2}$, and Widi Wurjani ${ }^{3}$ \\ ${ }^{1}$ Chemical Engineering Department, Faculty of Engineering, Universitas Pembangunan Nasional "Veteran" Jawa Timur, Indonesia \\ ${ }^{2}$ Industrial Engineering Department, Faculty of Engineering, Universitas Pembangunan Nasional "Veteran" Jawa Timur, Indonesia \\ ${ }^{3}$ Agrotechnology Department, Faculty of Agriculture, Universitas Pembangunan Nasional "Veteran” Jawa Timur, Indonesia
}

\begin{abstract}
Abstrak. The increase in plastic production worldwide has created quite a serious environmental problem. Edible film is an alternative packaging that can decompose naturally, one of the materials that can be used to make edible films is starch. This study aims to determine the composition of corn cob starch and plasticizers that can produce edible films with the best properties. The starch used is derived from corn cobs and the plasticizers used are glycerol and sorbitol. The edible film in this study was made by the casting method by dispersing the raw materials, heating the mixture, printing the edible film and drying the edible film. This research was conducted with variations in the corncob of 5,6 and 7 in grams and the variation of the ratio of glycerol to sorbitol plasticizer is $2: 8 ; 3: 7 ; 5: 5 ; 7: 3 ; 8: 2(\mathrm{ml})$. The more starch content increases the thickness of the edible film and tensile strength, but the elongation and water vapor permeability decreases, the best edible film is obtained at the glycerol-sorbitol composition ratio of 5:5 with the amount of corncob starch of 7 grams.
\end{abstract}

Keywords: Corn cobs, Edible film, optimization, Surface response method

\section{Introduction}

The increasing production of plastic around the world is causing serious problems for the environment. This is because plastic is difficult to decompose in nature, Edible film is an alternative packaging that can decompose naturally. Edible film is defined as a thin polymer layer that serves as a barrier to gas and moisture that can be consumed. The components that are often used to make edible films are divided into three categories, namely hydrocolloids, lipids, and composites. A non-volatile plasticizer was added to the hydrocolloid film formation as a solution to renew the flexibility of the edible film. Plasticizers that are often used are: glycerol, sorbitol, polyethylene glycol and oligosaccharides. Glycerol is known as a hydrophilic plasticizer, so it is suitable to be added to hydrophobic film-forming materials such as starch, pectin, gel, and protein. Glycerol acts as a plasticizer to increase the flexibility of the film [1]. Starch, a polymer that is often used as a raw material in the manufacture of edible films, is often used in the food industry as a biodegradable film that aims to replace plastic polymers because it is economical, renewable, and provides good physical characteristics [2]. The use of a single material in the manufacture of edible films still has several shortcomings, including brittle and rigid properties, it is necessary to add additional materials, namely plasticizers [3]. Plasticizer is known as an additive in the manufacture of edible films which serves to increase the elastic properties [4].

Edible film has optimum conditions, namely when the composition of the mixture can produce physical and mechanical test values according to the standard, the more starch concentration used, the better the edible film properties obtained. Corn starch with the best composition obtained was 3\% corn starch concentration and $7 \%$ black turmeric juice, with the characteristics of the edible film being water vapor transmission 0.50 gram $/ \mathrm{m}^{2}$.hour, thickness $0.17 \mathrm{~mm}$, tensile strength $7.90 \mathrm{~N} /$ $\mathrm{cm}^{2}$, and elongation. concentration of plasticizer, the type of plasticizer used also greatly affects the characteristics of the edible film. The raw material of kolang kaling with plasticizer is glycerol, sorbitol, and polyethylene glycol [5]. The best treatment obtained is the use of sorbitol with a concentration of $3 \%$ with the resulting parameter values are $0.12 \mathrm{~mm}$ thick, water vapor transmission rate 4.34 gram $/ \mathrm{m}^{2}$ hour, tensile strength $2.83 \mathrm{~N} / \mathrm{cm}^{2}$ and percent elongation $44.65 \%$. edible films such as tensile strength, percent increase in length of edible film and water vapor permeability [6]. Starch is a material that is often used by the food industry as a biodegradable film that functions to replace plastic polymers because it is economical, renewable, and provides good physical characteristics [6].

Corn cobs are the largest part of corn waste. The content contained in corn cobs is cellulose as much as 40$60 \%$, hemicellulose as much as $20-30 \%$ and lignin as

Corresponding author : ketutsari.tk@upnjatim.ac.id 
much as $25-30 \%$. The starch content in corn cobs is $27.1 \%$ [7]. The nature of starch is suitable for edible films because it can form a fairly strong film. Starch-based edible films have weaknesses, namely low water resistance and low moisture barrier because the hydrophilic nature of starch can affect its stability and mechanical properties [8].

Sorbitol which acts as a plasticizer in the formation of edible films can reduce the permeability of the film to oxygen, reduce the brittleness of the film so that the elasticity of the film increases. Sorbitol is also commonly used as an additive in edible films as an artificial sweetener [9]. Hydrothermal modification of physical properties in making edible film from red bean starch [10], use of sweetener food additives [11].

\subsection{Characteristic Standard Edible Film}

Based on the Japanese Industrial Standard (JIS), edible films have a maximum standard thickness of $0.25 \mathrm{~mm}$, a minimum tensile strength of $0.392 \mathrm{MPa}$, a maximum water vapor transmission rate of $10 \mathrm{~g} / \mathrm{m} 2$ day, and elongation has a minimum standard of $10 \%$ [12]. Factors that need to be considered in the manufacture of edible films are temperature, plasticizer and material concentration. Heating is carried out during mixing. This is done with the aim of achieving perfect starch gelatinization, in the manufacture of edible films a temperature of $\pm 70^{\circ} \mathrm{C}$ is used [1]. Plasticizing agents are needed as additional ingredients in the manufacture of edible films with the aim of overcoming the brittleness of edible films caused by intensive intermolecular forces. Plasticizers increase the mobility of the polymer chains, thereby increasing the flexibility of edible films [13]. The concentration of raw materials is very influential, especially on the physical properties of edible films. The more concentration of raw materials added, the thicker and greater the tensile strength [14]. In the manufacture of this edible film, starch from corn cobs is used as raw material. Starch from corn cobs is very safe for human consumption because it does not endanger health. The plasticizers used are glycerol and sorbitol. According to the regulation of the POM RI No. 5 of 2013 concerning the maximum limit for the use of humectant food additives and No. 4 of 2014 concerning the maximum limit for the use of sweetener food additives, the limit on the use of glycerol and sorbitol for edible packaging, which is in accordance with CPPB. The maximum CPPB limit is the amount of BTP that is allowed to be present in food in sufficient quantities needed to produce the desired effect and its use should not be excessive [15].

\subsection{Result Optimization}

Response Surface Methodology (RSM) is a collection of mathematical and statistical methods used in modeling and analysis, which aims to see the effect of several quantitative variables on a response variable and to optimize the response variable. The relationship between response $\mathrm{Y}$ and the independent variable $\mathrm{X}$ :

$$
Y=f\left(X_{1}, X_{2}, . . X_{k}\right)+\varepsilon
$$

Where:

$\mathrm{Y}=$ response variable

$\mathrm{X}=$ independent variable/factor

$\varepsilon=$ error

The first step of RSM is to find the relationship between the response and the independent variable through the appropriate approach, between the response and the independent variable is a linear function, the function approach is called the first-order model, as shown in the following equation.

$$
Y=\beta o+\sum_{i=1}^{k} \beta o X i
$$

If the form of the relationship is a quadratic, then for the function approach, a higher degree polynomial is used, namely the second-order model

$$
Y=\beta_{\mathrm{o}}+\sum_{\mathrm{i}=1}^{\mathrm{k}} \beta_{\mathrm{o}} X_{\mathrm{i}}+\sum_{\mathrm{i}=1}^{\mathrm{k}} \beta_{\mathrm{u}} X_{\mathrm{i}}^{2}+\sum_{\mathrm{i}=1, \mathrm{j}=2}^{\mathrm{k}-1, \mathrm{k}} \beta_{\mathrm{i}, \mathrm{j}} X_{\mathrm{i}} X_{\mathrm{j}}+\varepsilon
$$

After obtaining the most suitable form of relationship, the next step is to optimize the relationship. Equations and optimization results are obtained using Minitab software. To check the significance of the model, we can see the pvalue of Regression. If the p-value is smaller than the degree of significance $(\alpha=5 \%)$, it can be said that these variables make a significant contribution to the model [16].

From previous research on edible films, in this study using starch from corncob waste weighing 5,6 and 7 as raw materials, using glycerol and sorbitol as plasticizers. Edible film is made by casting method by dispersing the raw material, heating the mixture, printing the edible film and drying the edible film.

\section{Methodology}

The materials used in this study were corn cobs, aquadest, carrageenan, $1 \% \mathrm{NaOH}$, glycerol and sorbitol.
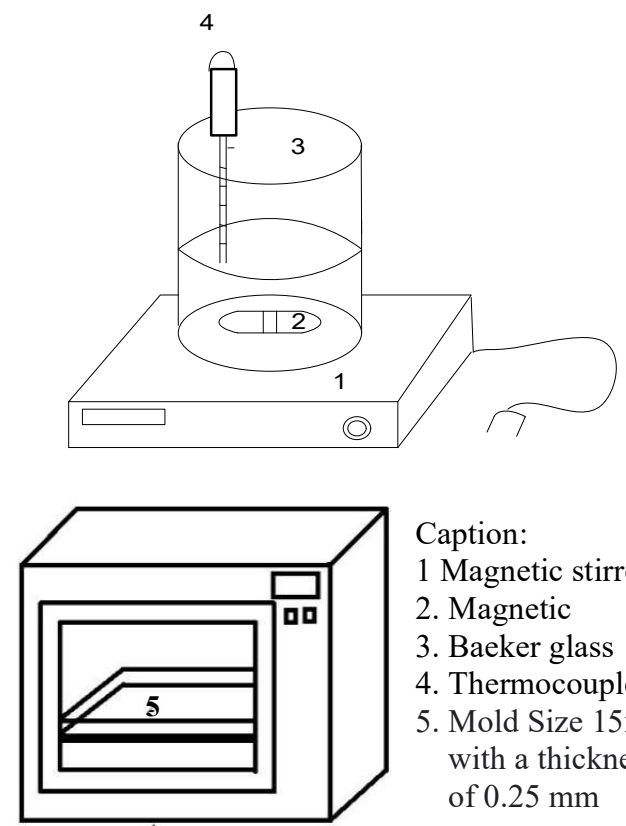

Caption: 1 Magnetic stirrer 2. Magnetic 3. Baeker glass

4. Thermocouple

5. Mold Size $15 \times 15 \mathrm{~cm}$ with a thickness of $0.25 \mathrm{~mm}$

Fig. 1. Research tools edible film from corn cobs 


\subsection{Starch Making}

Making starch from corn cobs is done by cutting the corn cobs into small pieces, soaked in $1 \% \mathrm{NaOH}$ for 12 hours to remove the lignin content. The corncobs were washed with water and ground, the pulp was squeezed out with a filter cloth, the filtrate was allowed to stand for one day to produce starch deposits. The starch precipitate was dried in the oven to remove the moisture content, after drying the starch was ground with a mortar until smooth, then sifted so that the size was homogeneous.

\subsection{Edible Film Making}

Starch from corn cobs was weighed with a weight of $5 \mathrm{gr}$, $6 \mathrm{gr}$, and 7 grams. Starch from corn cobs was added with a mixture of glycerol and sorbitol in a ratio of 2:8, 3:7, $5: 5,7: 3,8: 2$ and then added with distilled water until the solution reached $100 \mathrm{ml}$ in a beaker glass. The mixture was stirred with a magnetic stirrer with a rotation of 400 $\mathrm{rpm}$, heated to a temperature of $\pm 70^{\circ} \mathrm{C}$ and stirred for 20 minutes. The edible film solution is still stirred while it is cooled to room temperature in order to prevent air bubbles from forming during printing. The edible film solution was printed on a glass plate and then dried at $60{ }^{\circ} \mathrm{C}$ for 7 hours. After drying, the film was cooled to room temperature.

\section{Result and Discussion}

After obtaining the results of the analysis and calculation of the mechanical and physical properties of edible films, optimization of the results was carried out to determine the optimum results of edible films with the Surface Response Method using the Minitab software application which was carried out according to the theoretical basis reference regarding Result Optimization.

Table 1. Value of tensile strength, elongation, thickness and permeability

\begin{tabular}{|c|c|c|c|c|c|}
\hline \multirow{2}{*}{$\begin{array}{c}\text { Starch weight } \\
\text { (grams) }\end{array}$} & $2: 8$ & $3: 7$ & $5: 5$ & $7: 3$ & $8: 2$ \\
\hline \multicolumn{5}{|c|}{ Rensile strength (MPa) } \\
\hline 5 & 0.066 & 0.128 & 0.104 & 0.1 & 0.09 \\
\hline 6 & 0.317 & 0.283 & 0.24 & 0.166 & 0.14 \\
\hline 7 & 0.536 & 0.528 & 0.491 & 0.318 & 0.213 \\
\hline \multicolumn{5}{|c|}{ Elongation (\%) } \\
\hline 5 & 10.2 & 14.6 & 15.1 & 19.7 & 21.4 \\
\hline 6 & 5.1 & 5.8 & 6.9 & 7.9 & 7.5 \\
\hline 7 & 4.1 & 4.6 & 6.1 & 6.5 & 6.5 \\
\hline \multicolumn{5}{|l|}{} \\
\hline 5 & 0.12 & 0.15 & 0.16 & 0.16 & 0.15 \\
\hline 6 & 0.18 & 0.19 & 0.19 & 0.19 & 0.17 \\
\hline 7 & 0.26 & 0.23 & 0.2 & 0.19 & 0.16 \\
\hline Permickness (mm) & 11.83 & 11.66 & 11.66 & 11.39 & 11.55 \\
\hline 5 & 11.33 & 11.21 & 10.66 & 10.67 & 10.47 \\
\hline 6 & 10.39 & 9.99 & 9.84 & 10.23 & 8.86 \\
\hline 7
\end{tabular}

The optimization results from Minitab software show that the overall data is second order. The optimization results will show the function of the response equation to the modified conditions such as the glycerol-sorbitol ratio and starch weight.

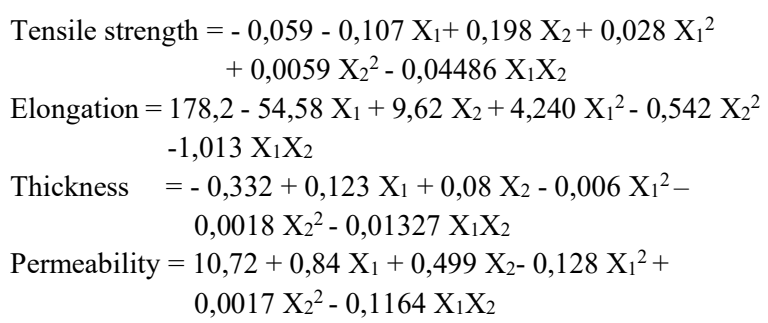

Note:

$\mathrm{X}_{1}=$ weight of starch

$\mathrm{X}_{2}=$ Ratio Glycerol to Sorbitol

Figure 2 shows the best tensile strength results have the darkest green color contour at a ratio of glycerol to sorbitol 2:8 and starch weight of 7 grams, this is due to the low ability of sorbitol to bind water thus limiting its ability to reduce hydrogen bonding of polymer chains compared to glycerol so that the strength The tensile strength of the film with sorbitol plasticizer is better than using glycerol plasticizer. The lowest results were shown in the ratio of glycerol to sorbitol 2:8 and starch weight of 5 grams, the small value of tensile strength was influenced by the small thickness of the edible film.

Contour plot of tensile strength versus ratio Glycerol to Sorbitol and starch weight

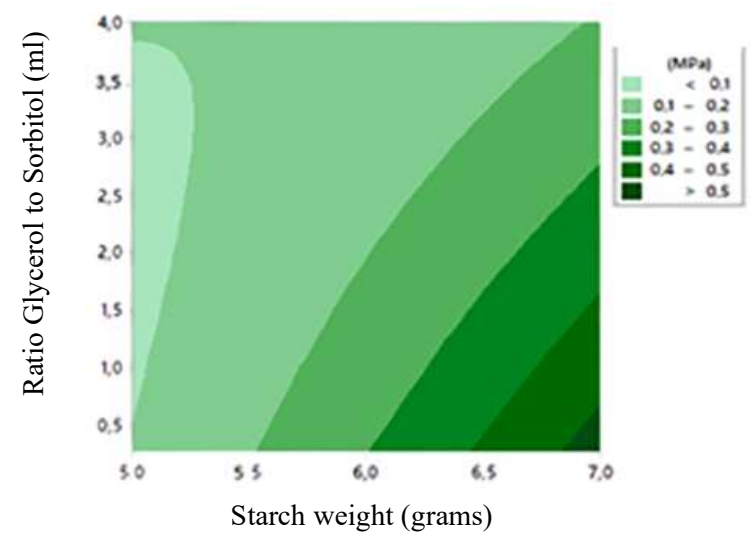

Fig. 2. Contour Plot Responses between GlycerolSorbitol Ratio and Starch Weight to Tensile Strength

Based on Figure 3, the best elongation results have a dark green color contour at a glycerol to sorbitol ratio of $8: 2$ and a starch weight of 5 grams. The lowest results were shown in the ratio of glycerol to sorbitol 2:8 and starch weight of 7 grams. This is because the increase in glycerol will decrease the intermolecular forces, as a result, the mobility between the molecular chains increases. The increase in glycerol will reduce the cohesive bonds between polymers which form a more elastic film. 


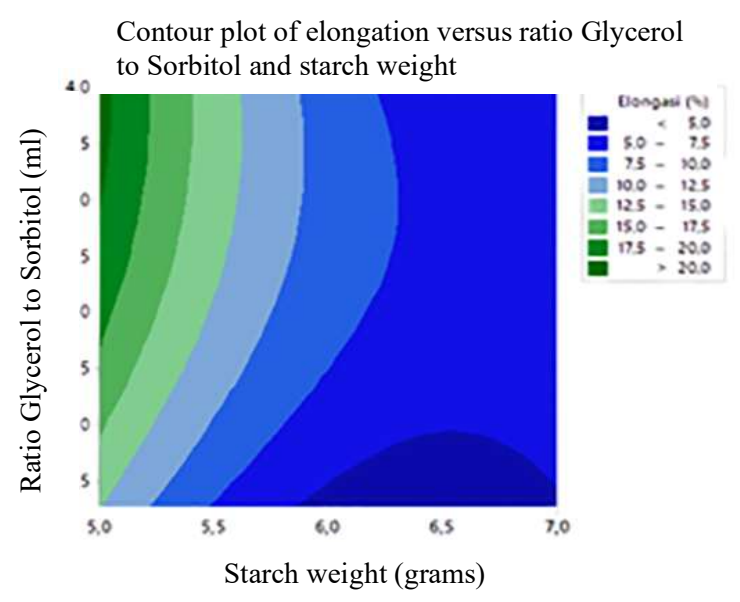

Fig. 3. Contour Plot Responses between GlycerolSorbitol Ratio and Starch Weight to Elongation

Based on Figure 4, the best water solubility results have a dark green color contour at a ratio of glycerol to sorbitol 2:8 and a starch weight of 7 grams. The lowest results were shown in the ratio of glycerol to sorbitol 2:8 and starch weight of 5 grams. The increase in the concentration of the material in the suspension of the edible film causes the total amount of solids contained in the edible film to increase, so that after the suspension of the edible film is dried, the edible film obtained is thicker.

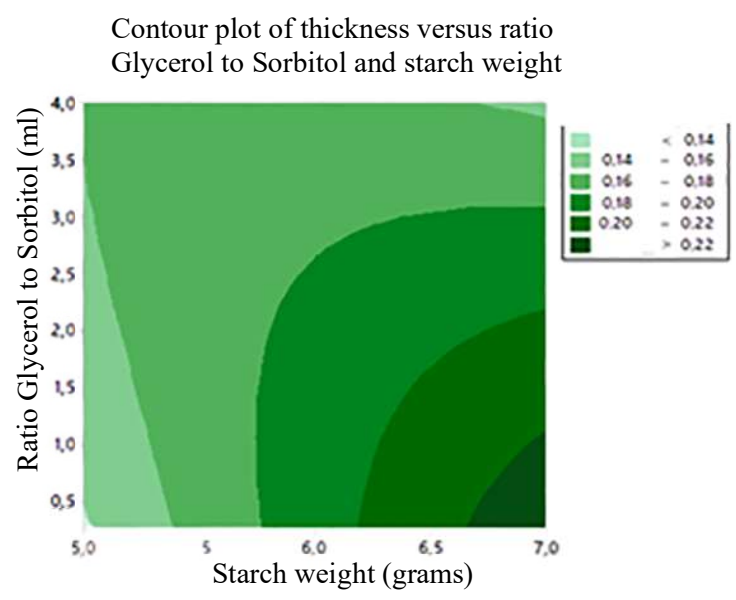

Fig. 4. Contour Plot Responses between GlycerolSorbitol Ratio and Starch Weight to Thickness

Based on Figure 5 the results of the best water solubility have the darkest color contour at the ratio of glycerol to sorbitol 2:8 and starch weight of 5 grams. The lowest results were shown in the ratio of glycerol to sorbitol 8:2 and starch weight of 7 grams. The effect of starch weight on the water vapor permeability of edible films can be seen that the more starch, the smaller the value of the water vapor permeability of the edible film. The high concentration of corncob starch will increase the amount of film-forming polymer. Increasing the amount of polymer will reduce the voids in the gel formed on the film. The thicker and denser the film matrix formed can reduce the rate of permeability because it is difficult for water vapor to penetrate.

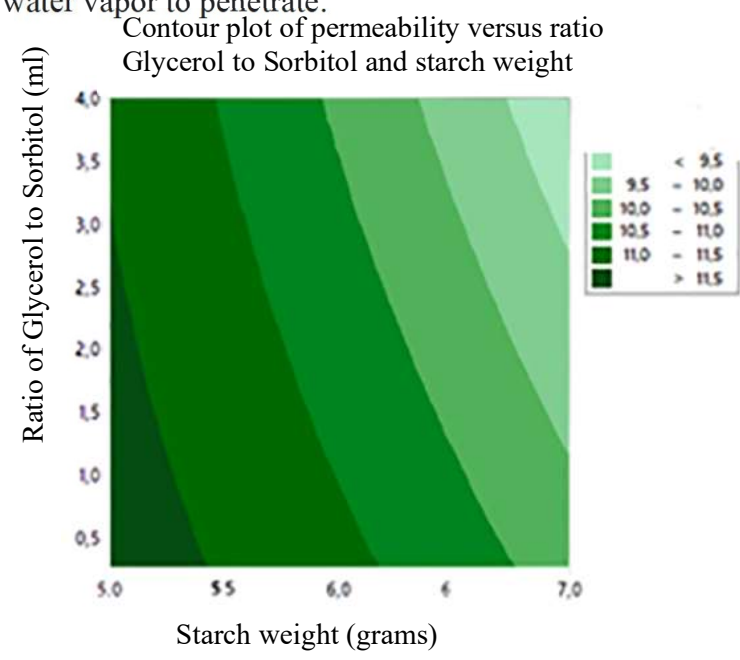

Fig. 5. Contour Plot Responses between GlycerolSorbitol Ratio and Starch Weight to Permeability

Based on Figure 6 shows the surface plot between the ratio of glycerol to sorbitol and starch to tensile strength. The best condition in Figure 6 is shown at the top point of the graph which shows the point of the glycerol to sorbitol ratio of 2:8 with a starch weight of 7 grams which produces a tensile strength of $0.536 \mathrm{MPa}$. While on the lowest surface showed the lowest results at the ratio of glycerol: sorbitol 2:8 with a starch weight of 5grams.

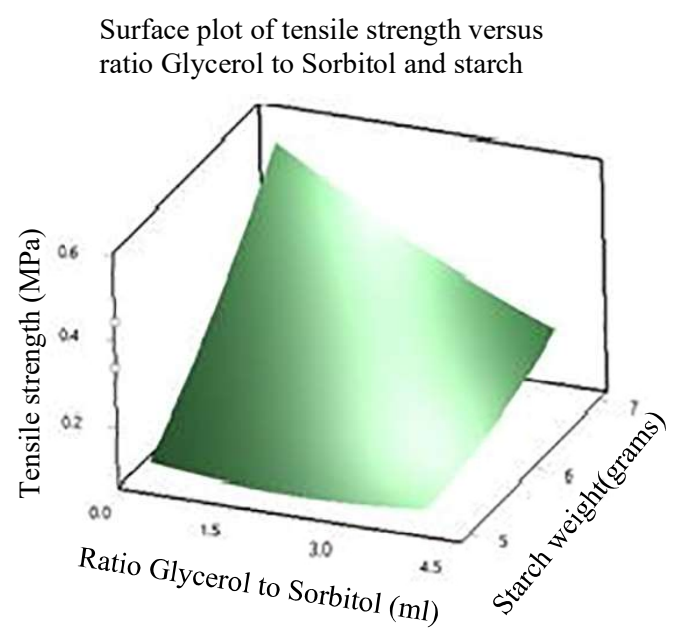

Fig. 6. Surface Characteristics Responses between Glycerol-Sorbitol Ratio and Starch Weight to Tensile Strength

Based on Figure 7 shows the surface plot between the ratio of glycerol to sorbitol and starch weight to elongation. The best condition in Figure 7 is shown at the top point of the graph which shows the point of the glycerol to sorbitol ratio of $8: 2$ with a starch weight of 5 grams which produces an elongation of $21.4 \%$. Meanwhile, on the lowest surface, the lowest yield was at the ratio of glycerol to sorbitol 2:8 with a starch weight of 7 grams. 


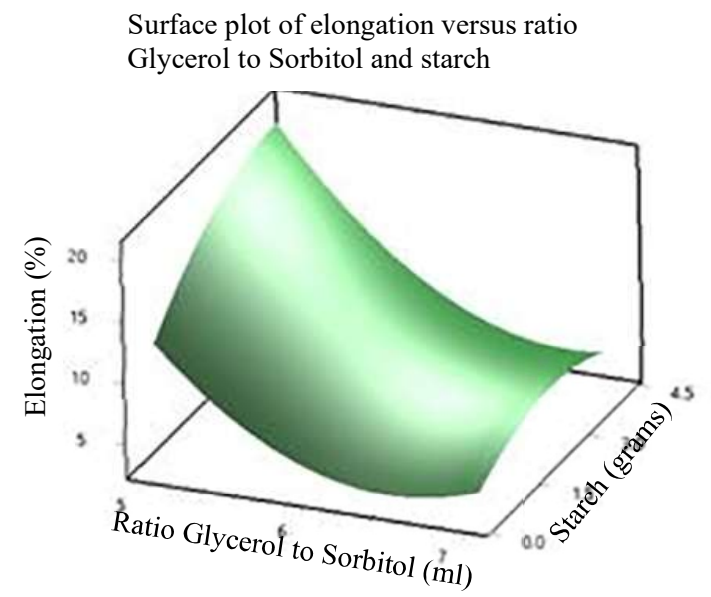

Fig. 7. Surface Characteristics Responses between Glycerol-Sorbitol Ratio and Starch Weight to Elongation

Based on Figure 8 shows the surface plot between the ratio of glycerol to sorbitol and starch weight to thickness. The best condition in Figure 8 is shown at the top point of the graph which shows the point of the ratio of glycerol to sorbitol 2:8 with a starch weight of 7 grams which produces a thickness of $0.26 \mathrm{~mm}$. While the lowest surface showed the lowest yield and the ratio of glycerol to sorbitol was 8:2 with a starch weight of 5 grams.

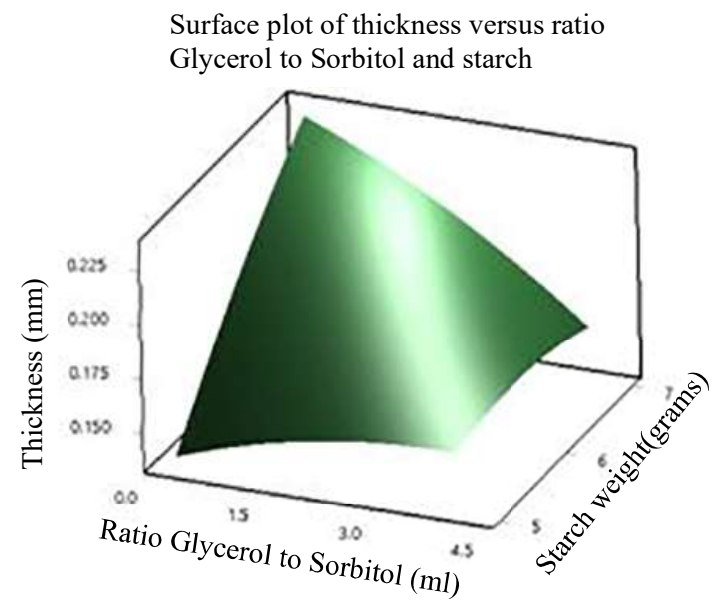

Fig. 8. Surface Characteristics Responses between Glycerol-Sorbitol Ratio and Starch Weight to Thickness

Based on Figure 9 shows the surface plot between the ratio of glycerol to sorbitol and starch weight to water vapor permeability. The best condition in Figure 9 is shown at the top point of the graph, which shows the ratio of glycerol to sorbitol 2:8 with a starch weight of 5 grams which results in a permeability of $11.83 \mathrm{~g} / \mathrm{m} 2$ day. While on the lowest surface, the lowest yield was at the ratio of glycerol to sorbitol 8:2 with a starch weight of 7 grams.
Surface plot of permeability versus ratio Glycerol to Sorbitol and starch

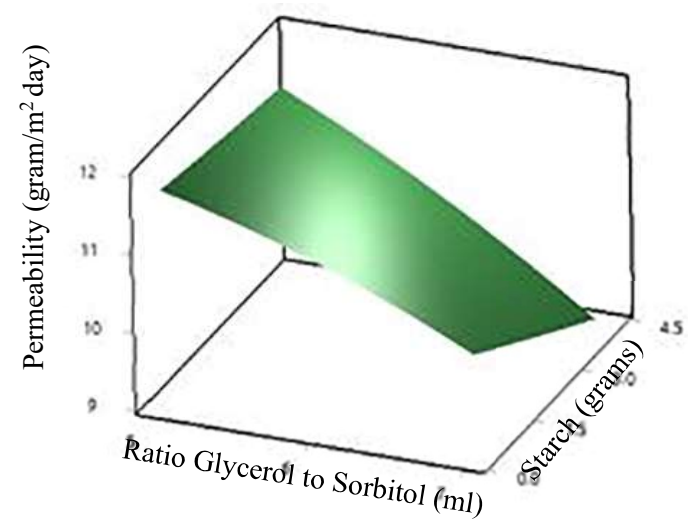

Fig. 9. Surface Characteristics Responses between Glycerol-Sorbitol Ratio and Starch Weight to Permeability

Based on Figure 10 shows treatment with the depiction of contour plots and surface plots with optimization using the Surface Response Method in the Minitab 18 software application, an optimization of the desired results with certain parameters can be carried out. The parameters of the optimization results are set to produce optimum edible film properties. The optimization results using the Surface Response Method resulted in optimum conditions at a glycerol-sorbitol ratio of 1.4242 or 5.875:4.125 with a lot of starch $7 \mathrm{~g}$ with edible film properties including tensile strength of $0.4230 \mathrm{MPa}$, elongation of $6.6478 \%$, vapor permeability water is $9.9168 \mathrm{gr} / \mathrm{m} 2$ day, and the thickness is $0.2148 \mathrm{~mm}$. The values of these properties are mostly in accordance with the Japanese Industrial Standard (JIS), but for elongation it is still not suitable. Then it is taken from conditions that are close to the optimum results, namely the glycerolsorbitol ratio of 1 or $5: 5$ and the amount of starch is 7 grams. 
Response optimization : permeability, thickness, elongation, tensile strength, and elongation

\begin{tabular}{llccccc}
$\begin{array}{l}\text { Parameters } \\
\text { Response }\end{array}$ & Goal & Lower & Target & Upper & Weight & Importance \\
\hline Permeability & Minimum & & 8.8617 & 10.00 & 1 & 1 \\
Thickness & Minimum & & 0.1200 & 0.26 & 1 & 1 \\
Elongasi & Minimum & 4.1 & 21.400 & & 1 & 1 \\
T. Strength & Minimum & 0.4 & 0.5360 & & 1 & 1
\end{tabular}

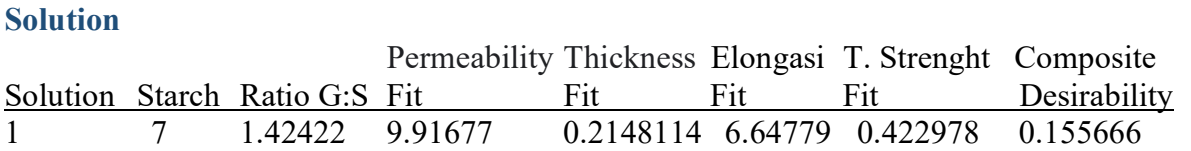

Multiple Response Prediction

\begin{tabular}{ll} 
Variable & Setting \\
\hline Starch & 7
\end{tabular}

Ratio G:S 1.42424

$\begin{array}{lllllll}\text { Response } & \text { Fit } & \text { SE Fit } & 95 \% \text { CI } & 95 \% \text { PI } & \\ \text { Permeability } & 9.917 & 0.162 & (9.551 . & 10.283) & (9.557 . & 10.666) \\ \text { Thickness } & 0.21481 & 0.00873 & (0.19506 . & 0.23457) & (0.17432 . & 0.25531) \\ \text { Elongasi } & 6.648 & 0.842 & (4.744 . & 8.552) & (2.745 . & 10.550) \\ \text { T. Strength } & 0.4230 & 0.0131 & (0.3933 . & 0.4526) & (0.3622 . & 0.4837)\end{array}$

Fig. 10. Output Optimization Results with Minitab Software

\section{Conclusion}

The resulting edible films have different characteristics depending on the variation of the plasticizer ratio between glycerol and sorbitol and the amount of starch. These characteristics include the value of tensile strength with the largest value of $0.536 \mathrm{MPa}$ and the smallest of 0.066 $\mathrm{MPa}$, the elongation value with the largest value of $21.4 \%$ and the smallest of $4.1 \%$, thickness with the largest value of $0.26 \mathrm{~mm}$ and the smallest of $0.12 \mathrm{~mm}$, and water vapor permeability with the largest value $11.83 \mathrm{gram} / \mathrm{m}^{2}$ day and the smallest $8.86 \mathrm{gram} / \mathrm{m}^{2}$ day. Where some are in accordance with the Japanese Industrial Standard (JIS) and existing theories. The optimum results were in the composition ratio of glycerol to sorbitol 5:5 with the amount of corncob starch of 7 grams.

\section{Acknowledgment}

The author would like to thank the financial support from the Ministry of Education, Culture, Research and Technology, the Republic of Indonesia with Applied Grants, Contract Number: 293/E4.1/AK.04.PT/2021

\section{References}

1. S.W. Murni, H. Pawignyo, W. Desi, N. Sari, Making Edible Film from Corn Flour (Zea Mays L.) and Chitosan, Proceedings of the National Seminar on Chemical Engineering "shock" page 1-4 (2013).

Pembuatan Edible Film dari Tepung Jagung (Zea Mays L.) dan Kitosan, Prosiding Seminar Nasional Teknik Kimia “Kejuangan”, hal. 1-4, (2013)
2. R. Yulianti and E. Ginting, Differences in Physical Characteristics of Edible Film from Tubers Made

with Addition of Plasticizers, Food Crops Agricultural Research, 31, 2, page 131 (2012). Perbedaan Karakteristik Fisik Edible Film dari Umbi-umbian yang Dibuat dengan Penambahan Plasticizer, Penelitian Pertanian Tanaman Pangan vol. 31, no. 2, hal. 131, (2012)

3. M.K. Wahyu, Utilization of Cassava Starch as Raw Material for Edible Film, Scientific Paper of Beswan Djarum, Department of Food Industry Engineering, University of Pandjajaran, Bandung, (2009). Pemanfaatan Pati Singkong Sebagai Bahan Baku Edible Film, Karya Tulis Ilmiah Beswan Djarum, Jurusan Teknik Industri Pangan Universitas Pandjajaran, Bandung, (2009)

4. D. Huri, and F.C. Nisa, Effect of Glycerol Concentration and Apple Peel Extract on Physical and Chemical Characteristics of Edible Film, Journal of Food and Agroindustry, 2, 4, page 30, (2014). Pengaruh Konsentrasi Gliserol dan Ekstrak Ampas Kulit Apel Terhadap Karakteristik Fisik dan Kimia Edible Film, Jurnal Pangan dan Agroindustri, vol. 2, no. 4, hal. 30, (2014)

5. A.J.W.S. Sitompul, and E. Zubaidah, The Effect of Plasticizer Type and Concentration on Physical Properties of Kolang Kaling (Arenga Pinnata) Edible Film, Journal of Food and Agroindustry, 5, 1, page 23, (2017). Pengaruh Jenis Dan Konsentrasi Plasticizer Terhadap Sifat Fisik Edible Film Kolang Kaling (Arenga Pinnata), Jurnal Pangan dan Agroindustri vol. 5, no. 1, hal. 23, (2017) 
6. D.H. Kusumawati, and W.D.R. Putri, Physical and Chemical Characteristics of Edible Corn Starch Film Incorporated with Black Cucumber Juice, Journal of Food and Agroindustry, 1, 1, page 91, (2013). Karakteristik Fisik Dan Kimia Edible Film Pati Jagung Yang Diinkorporasi Dengan Perasan Temu Hitam, Jurnal Pangan dan Agroindustri vol. 1, no. 1, hal. 91, (2013)

7. M.E. Shofiyanto, Hydrolysis of Corn Cobs by Cellulolytic Bacteria for Bioethanol Production in Mixed Cultures, Thesis of the Department of Agricultural Industrial Technology, University of Agricultural Bogor (2008). Hidrolisis Tongkol Jagung oleh Bakteri Selulolitik untuk Produksi Bioetanol dalam Kultur Campuran, Skripsi Departemen Teknologi Industri Pertanian, Institut Pertanian Bogor, (2008)

8. C. Winarti, Widaningrum, and Miskiyah, Production Technology and Application of Starch-Based Antimicrobial Edible Packaging, Journal of Agricultural Research and Development, 31, 3, page 85, (2012). Teknologi Produksi dan Aplikasi Pengemas Edible Antimikroba Berbasis Pati, Jurnal Litbang Pertanian, vol. 31, no. 3, hal. 85, (2012)

9. R. Effendi, A.D. Putra, and V.S. Johan, Addition of Sorbitol as Plasticizer in Making Edible Film Starch Breadfruit, JOM Faculty of Agriculture, 4, 2, page 23, (2017). Penambahan Sorbitol Sebagai Plasticizer Dalam Pembuatan Edible Film Pati Sukun', JOM Fakultas Pertanian, vol. 4, no. 2, hal. 2-3, (2017)

10. D.D.A. Krisna, Effect of Regelatination and Hydrothermal Modification on Physical Properties in Making Edible Film from Red Bean Starch (Vigna Angularis sp.), Thesis, Master Program in Chemical Engineering, Diponegoro University, Semarang (2011). Pengaruh Regelatinasi Dan Modifikasi Hidrotermal Terhadap Sifat Fisik Pada Pembuatan Edible Film Dari Pati Kacang Merah (Vigna Angularis sp.), Tesis, Program Studi Magister Teknik Kimia Universitas Diponegoro, Semarang, (2011)

11. Maximum Limit of Use of Sweetener Food Additives, Food and Drug Supervisory Agency, Jakarta, Regulation of the Head of the Food and Drug Supervisory Agency of the Republic of Indonesia Nomor 4 (2014). Batas Maksimum Penggunaan Bahan Tambahan Pangan Pemanis, Badan Pengawas Obat Dan Makanan, Jakarta, Peraturan Kepala Badan Pengawas Obat Dan Makanan Republik Indonesia Nomor 4 Tahun 2014

12. M. Firmansyah, and K. Syahnaz, Edible Film Made from Cowpea Protein Concentrate and Kupang Skin Chitosan, Research Report, UPN "Veteran" East Java, Surabaya (2018). Edible Film Berbahan Konsentrat Protein Kacang Tunggak Dan Kitosan Kulit Kupang', Laporan Penelitian, UPN “Veteran” Jawa Timur, Surabaya, (2018)

13. H. Helen, and L. Hyvonen, Preparation, Properties and Applications of Wheat Gluten Edible Film, Argicultural and Food Science, 9, 24, (2000)

14. Maximum Limit for Use of Humectant Food Additives, Food and Drug Supervisory Agency, Jakarta, Regulation of the Head of the Food and Drug
Supervisory Agency of the Republic of Indonesia Number 5 (2013). Batas Maksimum Penggunaan Bahan Tambahan Pangan Humektan, Badan Pengawas Obat Dan Makanan, Jakarta, Peraturan Kepala Badan Pengawas Obat Dan Makanan Republik Indonesia Nomor 5 Tahun 2013

15. G. Kavas, N. Kavas, and D. Saygili, The Effects of Thyme And Clove Essential Oil Fortified Edible Films on The Physical, Chemical And Microbiological Characteristics of Kashar Cheese, Journal of Food Quality, 38, page 405-406, (2015)

16. R. Faulina, S. Andari, and D. Angraeni, Response Surface Methodology (RSM) and Its Applications, Research Report, Sepuluh Nopember Institute of Technology, Surabaya, (2011). Response Surface Methodology (RSM) dan Aplikasinya', Laporan Penelitian, Institut Teknologi Sepuluh Nopember, Surabaya, (2011) 